\title{
24. MASS-ACCUMULATION RATES OF BARREMIAN TO RECENT BIOGENIC SEDIMENTS FROM THE MID-PACIFIC MOUNTAINS (DEEP SEA DRILLING PROJECT SITE 463) AND HESS RISE (SITES 464, 465, AND 466), CENTRAL NORTH PACIFIC OCEAN ${ }^{1}$
}

\author{
Jörn Thiede, Department of Geology, University of Oslo, Postboks 1047, Blindern, Oslo 3, Norway \\ and \\ David K. Rea, Oceanography Program, Department of Atmospheric and Oceanic Science, \\ The University of Michigan, Ann Arbor, Michigan
}

\begin{abstract}
Accumulation rates (expressed in $\mathrm{g} \cdot \mathrm{cm}^{-2} \cdot \mathrm{yr}^{-1} 10^{-3}$ ) have been calculated for the main biogenic components (calcite, opal, and organic carbon) of upper Mesozoic to Cenozoic pelagic sediments collected during Deep Sea Drilling Project Leg 62 from two structural highs in the central North Pacific Ocean. Drilling at Site 463, on the western MidPacific Mountains, penetrated a calcareous sediment column of Barremian to Pleistocene age. Accumulation rates of calcareous material are highest $\left(>10 \mathrm{~g} \cdot \mathrm{cm}^{-2} \cdot \mathrm{yr}^{-1} 10^{-3}\right)$ in the Lower Cretaceous, deepest part of the site, where displaced shallow-water material is intercalated with pelagic limestones. During the middle Cretaceous, when carbonaceous shale and limestone were being deposited along the flanks of the partly subaerial western Mid-Pacific Mountains, calcite accumulation rates dropped to 1.5 to $4.0 \mathrm{~g} \cdot \mathrm{cm}^{-2} \cdot \mathrm{yr}^{-1} 10^{-3}$, although in a number of intervals high concentrations of siliceous fossils and organic carbon have been preserved. The Cenozoic portion of the sedimentary section of Site 463 is characterized by a slow accumulation (e.g., $<0.5 \mathrm{~g} \cdot \mathrm{cm}^{-2} \cdot \mathrm{yr}^{-1} 10^{-3}$ ) of calcareous oozes, interrupted at least three times by major hiatuses. Site 464 , on the northern extension of Hess Rise, and Sites 465 and 466 , on the southern part of Hess Rise, penetrated Pleistocene to mid-Cretaceous pelagic sediments which accumulated more slowly $\left(<2 \mathrm{~g} \cdot \mathrm{cm}^{-2} \cdot \mathrm{yr}^{-1} 10^{-3}\right)$, except during deposition of part of the Mesozoic basal sequences of all three sites, when accumulation rates of the total sediment and of calcareous material were extraordinarily high. Hiatuses interrupted sediment accumulation during the Mesozoic and Cenozoic at all three sites on Hess Rise for long time intervals.
\end{abstract}

\section{INTRODUCTION}

\section{Background}

The evolution of a depositional environment can be typified through the measurement of a multitude of variables. Accumulation rates expressed in units of mass per area and time of single and well-defined sediment components are some of the best parameters because they are not affected by the increasing age and overburden of sediments or by differences in age or lithology (van Andel et al., 1975). However, their calculation requires the measurement of a diverse set of physical properties, age, and sediment characteristics, which are not available from many samples; this usually results in a restricted data base. In this study we want to consider the accumulation rates of the major biogenic constituents of Mesozoic and Cenozoic pelagic sediments penetrated and sampled on two structural highs in the central North Pacific Ocean (Fig. 1). Site 463, on the western extension of the Mid-Pacific Mountains, and Sites 465 and 466 , on the southern part of Hess Rise, have been above the calcite-compensation depth (CCD) during Cretaceous and Cenozoic time, so their sedimentary column is essentially calcareous and other components are of minor importance. Only Site 464, on the northern part of Hess Rise, is deep enough and far enough north that-except during a few million years of its earliest history - the upper part of its sedimentary column con-

\footnotetext{
1 Initial Reports of the Deep Sea Drilling Project, Volume 62.
}

sists of dominantly non-calcareous sediments which accumulated very slowly. Locations of drill holes cited in this study are given in Table 1. Stratigraphy of the sites is shown in Figure 2. This study is complimentary to the studies of Rea and Janecek and of Rea and Harrsch (both this volume) which describe and discuss massaccumulation rates of non-authigenic, inorganic, crystalline, probably eolian components of these four sites. Data similar to those presented in this study also have been calculated for Site 462 , in the Nauru Basin west of the Marshall Islands (Rea and Thiede, 1981).

\section{Stratigraphy of the Drill Sites}

Site 463 (western Mid-Pacific Mountains) is situated in 2525 meters of water and penetrated a dominantly calcareous sequence of oozes, chalks, and limestones, ranging in age from Barremian to Pleistocene. Lithologic variations of these calcareous deposits allow us to subdivide them into four major units. The oldest consists of more than 190 meters of pelagic limestone interbedded with shallow-water carbonate debris, which occurs with increasing abundance toward the base. The overlying unit is 45 meters thick and is composed of cyclic, in part carbonaceous limestones of early Aptian age, with a number of distinct dark volcanic-ash horizons. The organic-carbon content of the individual carbonaceous horizons reaches values in excess of $4 \%$ (Dean et al., this volume). The two younger units consist of Aptian to middle Albian multicolored pelagic limestone beds with chert as a common component, and upper Albian to Pleistocene nannofossil and foramin- 


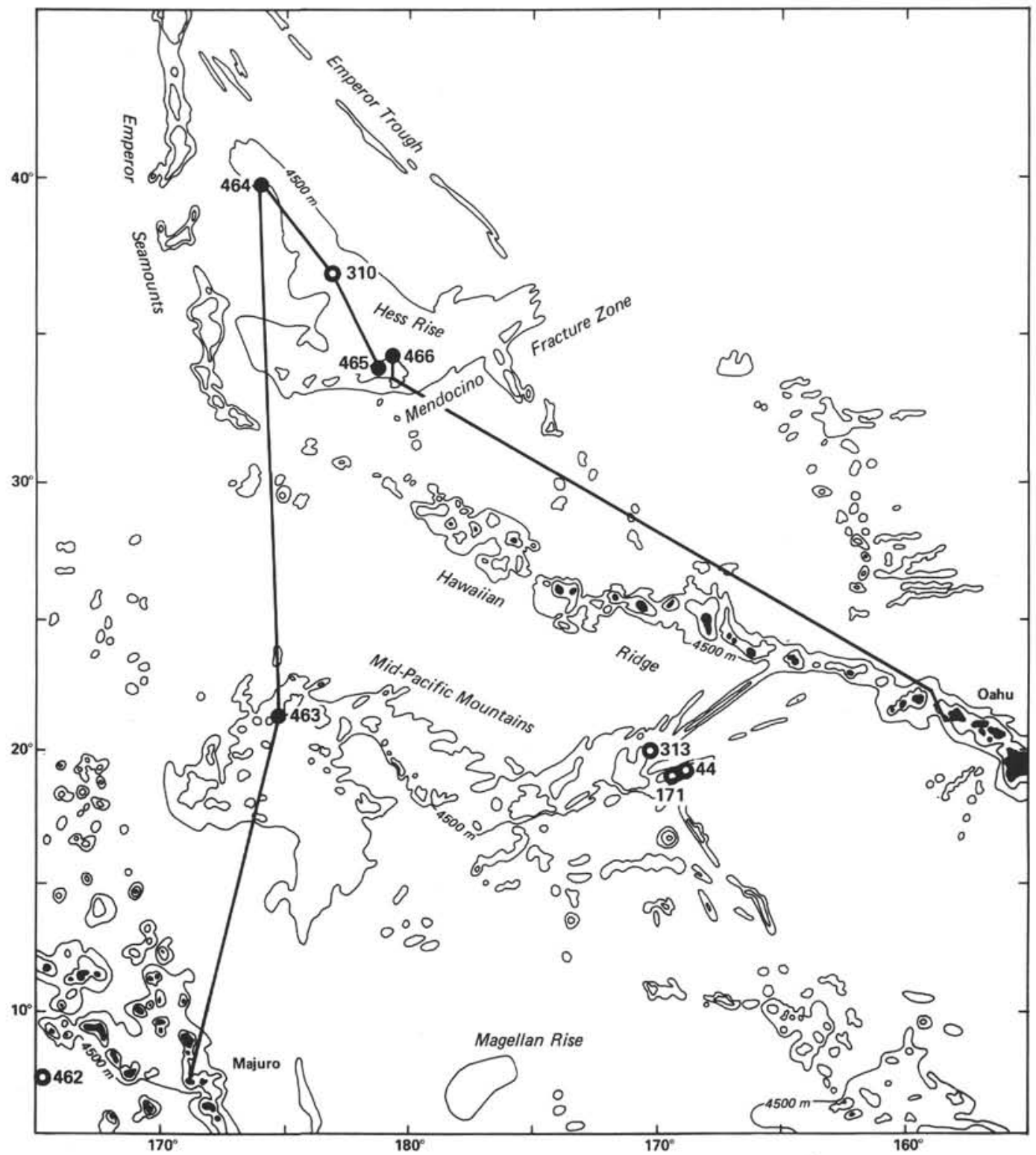

Figure 1. Location of DSDP Leg 62 drill sites in the central North Pacific Ocean.

Table 1. Locations of DSDP Leg 62 drill holes in the central North Pacific Ocean.

\begin{tabular}{lccccl}
\hline Hole & Latitude & Longitude & $\begin{array}{c}\text { Water } \\
\text { Depth } \\
(\mathrm{m})\end{array}$ & $\begin{array}{c}\text { Penetration } \\
(\mathrm{m})\end{array}$ & $\begin{array}{c}\text { Age of } \\
\text { Oldest Sediment }\end{array}$ \\
\hline 463 & $21^{\circ} 21.0^{\prime} \mathrm{N}$ & $174^{\circ} 40.07^{\prime} \mathrm{E}$ & 2525 & 822.5 & late Barremian \\
464 & $39^{\circ} 51.64^{\prime} \mathrm{N}$ & $173^{\circ} 53.33^{\prime} \mathrm{E}$ & 4637 & 308.5 & early Albian \\
465 & $33^{\circ} 49.23^{\prime} \mathrm{N}$ & $178^{\circ} 55.14^{\prime} \mathrm{E}$ & 2161 & 96.0 & early Maastrichtian \\
$465 \mathrm{~A}$ & $33^{\circ} 49.23^{\prime} \mathrm{N}$ & $178^{\circ} 55.14^{\prime} \mathrm{E}$ & 2161 & 476.0 & late Albian \\
466 & $34^{\circ} 11.46^{\prime} \mathrm{N}$ & $179^{\circ} 15.34^{\prime} \mathrm{E}$ & 2665 & 312.0 & late Albian \\
\hline
\end{tabular}

ifer oozes and chalks, as well as some limestone. Hiatuses interrupt the two younger units several times, and both calcareous faunas and floras show signs of severe dissolution despite the shallow depth of the site.

Sites 464, 465, and 466 were drilled on Hess Rise: Site 464 in 4637 meters of water on the western flank of its northern tip, and 465 and 466 adjacent to each other at depths of 2161 and 2665 meters, respectively, along the southern boundary of Hess Rise, which follows the Mendocino Fracture Zone. Coring at these sites sampled not only widely distinct parts of Hess Rise but also water depths more than 2500 meters apart. Surprisingly, the sediments encountered at all three sites range in age to just over 100 m.y., but their lithologies are very distinct because of the differences in location and water depths.

Because of the location on crust situated well north of the equator for most of the past $100 \mathrm{~m} . \mathrm{y}$., and because of the depth, most of the sediments of Site 464 deposited during the past 95 m.y. consist of brown clays or clayey siliceous oozes to siliceous clays. This part of the sequence is particularly difficult to date, because of the scarcity of fossils, although siliceous fossils in the youngest part (Sancetta, this volume) and fish bones and scales in its older part (Doyle and Riedel, this 
volume) have allowed gross age assignments. These biostratigraphies do not allow precise definition of hiatuses, and overall accumulation rates therefore remain very low. The oldest interval of the deposits sampled at Site 464 , however, is comprised of a chert, chalk, and marlstone series of mid-Cretaceous age, which accumulated rapidly when the site was crossing beneath the equatorial high-productivity zone (Lancelot and Larson, 1975; Lancelot, 1978).

Holes 465 and $465 \mathrm{~A}$, on southern Hess Rise, penetrated a Pleistocene to upper Albian sequence of calcareous oozes and chalk above a highly altered, probably subaerially extruded (Seifert et al., this volume) trachyte basement. Outstanding sedimentary features of this site are the olive-gray laminated upper Albian to Cenomanian limestones that have occasionally high contents of organic carbon, and the apparently complete section across the Cretaceous/Tertiary boundary (Boersma, this volume). The continuity of the overlying sequence of Cenozoic calcareous ooze is interrupted by a long-lasting ( $>50$ m.y.) hiatus. The volcanic basement and the benthic fossils preserved in the older parts of the section document a location of this site close to the $\mathrm{Al}$ bian sea surface and enable a well-controlled reconstruction of the depositional paleoenvironment along southern Hess Rise.

Site 466 is also on the southern part of Hess Rise, but in somewhat deeper water than Site 465 , which is about $50 \mathrm{~km}$ to the southwest. The stratigraphic sequence of Site 466 is very similar to that at Site 465 , consisting of a largely calcareous section with a basal unit of olivegray, organic-carbon-rich nannofossil chalk and limestone of late Albian and early Cenomanian age. The overlying sequence is nannofossil ooze with some chert in its oldest part, but the continuity of this sequence is interrupted by two hiatuses which span 4 to $38 \mathrm{~m}$.y. and 48 to 70 m.y.

All four sites had been selected to typify the depositional paleoenvironments along the elevated parts of aseismic rises in regions of the North Pacific Ocean where such information had not been available. Data from these sites therefore have to be seen in conjunction with the information collected during the earlier DSDP cruises in the region, in particular from Legs 6, 17, 32, and 61. The unexpected occurrence of long-lasting hiatuses in the Cenozoic of the four Leg 62 sites and of horizons containing large amounts of displaced, in part older, material has made it difficult to interpret the sedimentary history at these locations as completely as had been hoped.

\section{METHODS}

Mass-accumulation rates of single sediment components can be calculated only if a number of diverse parameters have been measured. The most important one is the mass-accumulation rate (expressed as $\mathrm{g} \cdot \mathrm{cm}^{-2} \cdot \mathrm{yr}^{-1} 10^{-3}$ ) of the bulk sediment, which can then be apportioned according to concentrations (expressed in weight percent or permil) of the sedimentary component to be investigated.

Mass-accumulation rates are calculated from linear sedimentation rates, which describe the lengths of the sediment column deposited per unit time, and from the dry-bulk densities of the sediments. Linear sedimentation rates require knowledge of the age and the depth of the samples; these have been taken from the site reports (this volume) for all four sites. The age of the samples is based on correlation of biostratigraphic data to absolute time scales completed during the Leg 62 post-cruise meeting (May, 1979) and may be subject to some revision. The time scale of Berggren and Van Couvering (1974) has been used for the Neogene, that of Hardenbol and Berggren (1978) for the Paleogene, and that of van Hinte (1976) for the Cretaceous part of the drill sites described here. Sediments at Sites 463,465 , and 466 are highly fossiliferous and can be correlated to these time scales without problems. At Site 464 on northern Hess Rise, however, a thick sequence of brown clay occurs between Cretaceous chalks, limestone, and cherts and a thin sequence of upper Neogene siliceous oozes and clays. Doyle and Riedel (this volume) have dated these brown clays using ichthyoliths. The age assignments for the brown clays of Site 464 obtained by this method are fairly imprecise, but seem to indicate a regular increase of age with depth. It has therefore been assumed for this study that the brown clays accumulated very slowly but continuously, although we cannot exclude the possibility that major hiatuses may have interrupted the sedimentary sequence.

Dry-bulk-density data have been calculated from physical-property measurements of the sediments (van Andel et al., 1975; Rea and Janecek, this volume). Porosities used are reported in the physicalproperty sections of the site reports (this volume); the density of the sediment has been assumed to be $2.7 \mathrm{~g} \cdot \mathrm{cm}^{-3}$. We attempted to obtain these variables for each core; however, where this was impossible, the value of the next deeper core has been used. The mass accumulation rates of the bulk sediment are listed in Tables 2 to 5. Good agreement has been found between these values and those of Rea and Janecek and of Rea and Harrsch (both this volume), who calculated mass-accumulation rates from laboratory measurements of the dry-bulk density of individual samples.

The concentrations of biogenic sediment components are expressed in weight percent, and averages for each core have been calculated. Individual values, however, have been obtained by different means. The following components have been discerned: calcareous fossils, which include nannofossils, foraminifers, and remains of a number of quantitatively minor benthic invertebrates; and siliceous components, which include diatoms, radiolarians, silicoflagellates, and sponge spicules. The most complete and consistent set of data has been taken from the smear-slide descriptions by adding the concentrations of all calcareous fossils (including the fraction of the sediment composed of unspecified calcareous grains) and all siliceous fossils. They have been listed in Tables 2 to 5 under " $\mathrm{CaCO}_{3}$ fossil" and " $\mathrm{SiO}_{2}$ fossil."

The concentrations of $\mathrm{CaCO}_{3}$ also have been determined by a number of chemical methods. Since most calcareous matter in deepsea sediment is biogenic, these values also have been used for the calculation of mass-accumulation rates of calcareous material, and they are listed in Tables 2 to 5 under " $\mathrm{CaCO}_{3}$ chemical." Most of these measurements have been obtained by the carbonate-bomb technique (Müller and Gastner, 1971) and by commonly used acid-leaching techniques in the course of shore-laboratory studies. The values used are listed in a paper by Dean (this volume). In a number of cores, concentrations of calcareous fossils seemed to exceed the concentrations of calcareous material determined chemically, probably because the visual estimates of the smear-slide analyses tend to overemphasize these components.

The concentrations of organic carbon in a number of samples were determined during Leg 62 using the $\mathrm{CHN}$ analyzer, and in shorelaboratory studies using Leco WR-12 analyses according to the procedures outlined by Boyce and Bode (1972) and by Bode (1973).

\section{TEMPORAL DISTRIBUTION OF ACCUMULATION RATES OF THE BULK SEDIMENT AND ITS BIOGENIC COMPONENTS}

The calculated accumulation rates of the bulk sediment and its biogenic components for all Leg 62 drill sites are listed in Tables 2 to 5, and are illustrated in part in Figures 3 to 6 . Because the drill sites are atop the flanks of structural highs where dominantly calcareous sediments have accumulated, the flux of calcareous components dominates the lithology at all locations except Site 464, on the deep northern extension of Hess 

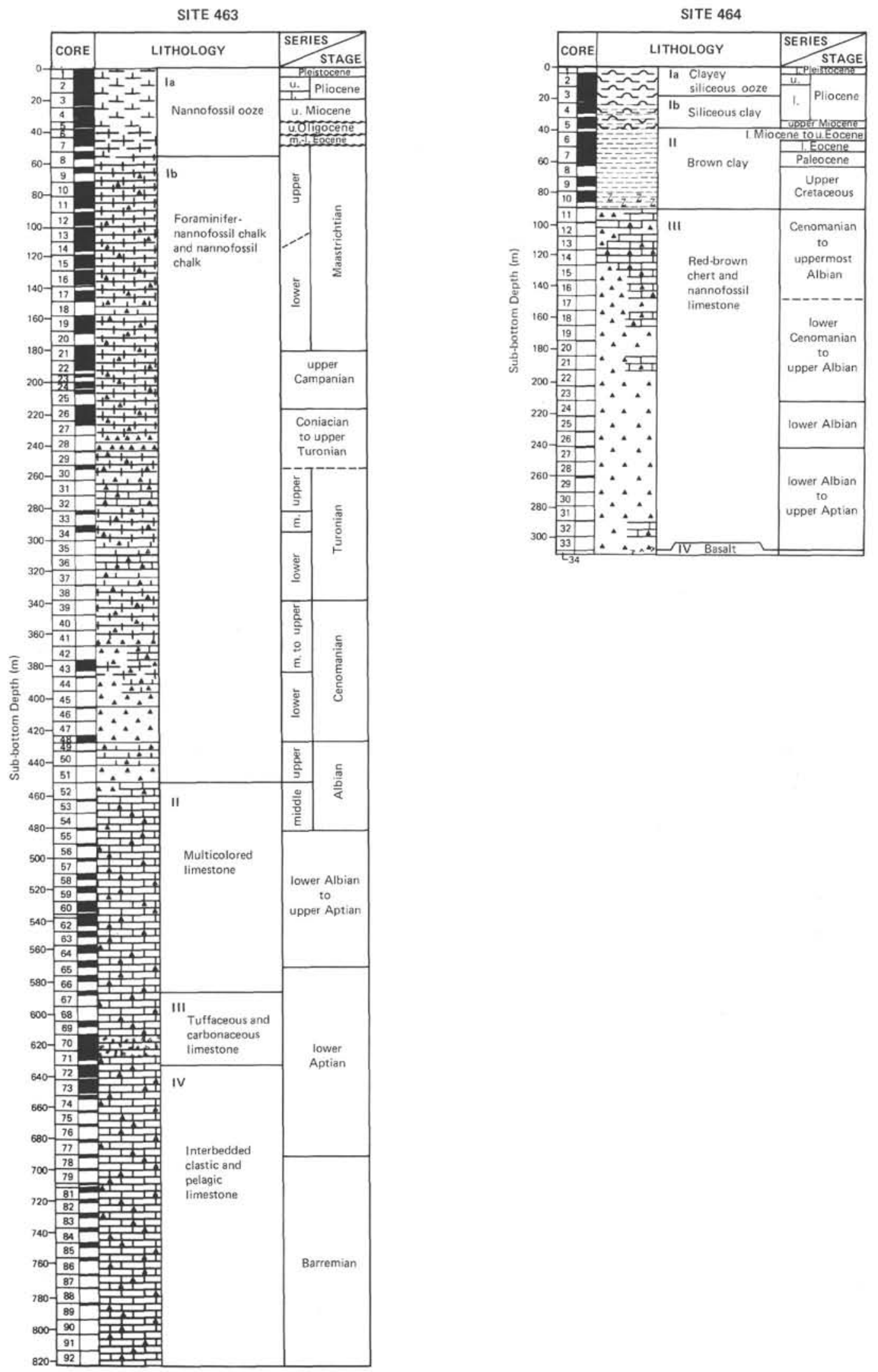

Figure 2. Stratigraphic subdivision of sediments penetrated at DSDP Site 463 (Mid-Pacific Mountains), and Sites 464, 465, and 466 (Hess Rise). 


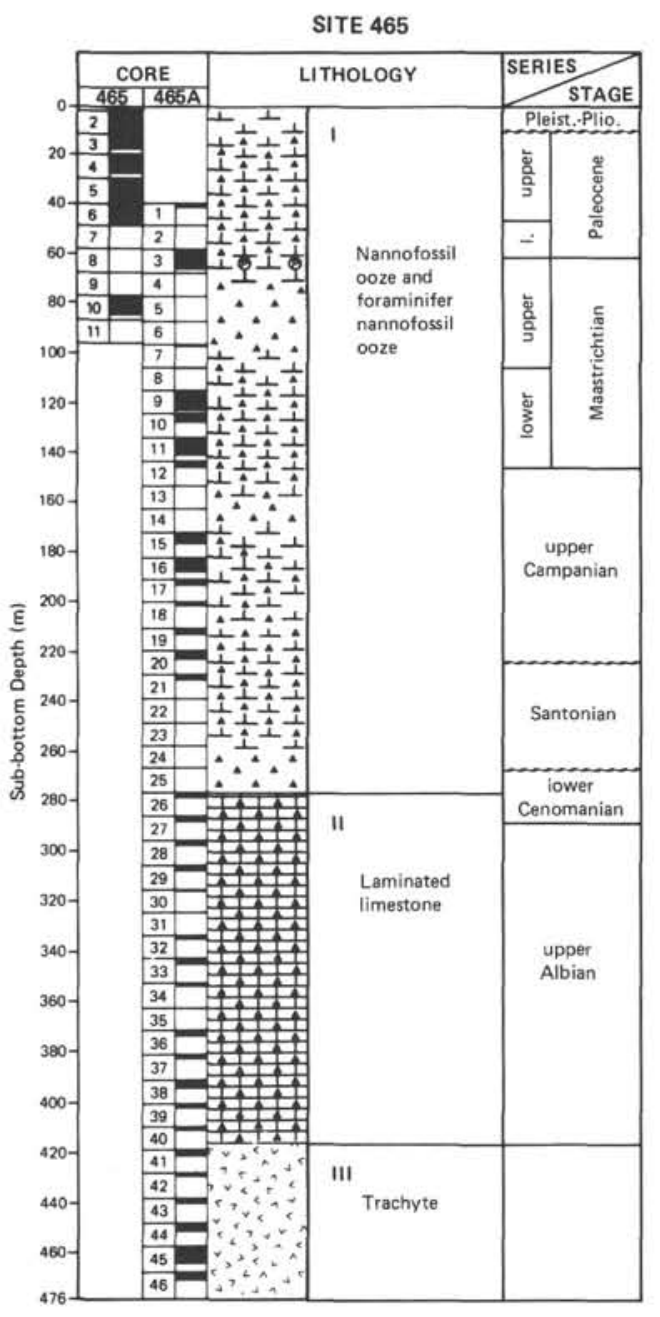

Figure 2. (Continued).

Rise; there, a sequence of carbonate-free brown clays, greater than 50 meters thick, represents a time span from approximately 98 to $10 \mathrm{~m} . \mathrm{y}$. , when the depositional surface was below the CCD and under lowproductivity surface waters of the central North Pacific subtropical gyre. It was not possible to calculate accumulation rates of the biogenic components in those cores of all sites where the only recovery was minor amounts of chert. There are no quantitative means available to estimate the proportion of chert in the entire sediment column, although the progress of drilling gives an indirect measure and indicates that the proportion of chert does not exceed about $5 \%$ (Hein et al., this volume). However, the lack of samples from these intervals precludes measurements of the variables needed for this study. It is interesting to note that chert generally is confined to intervals with higher mass-accumulation rates ( 1 to $\left.4 \mathrm{~g} \cdot \mathrm{cm}^{-2} \cdot \mathrm{yr}^{-1} 10^{-3}\right)$ of bulk sediment. Such values are typical of the northern and the southern fringes of the zone of high productivity under the equatorial current regime (van Andel et al., 1975).

Accumulation rates of the bulk sediment, as well as the dominant calcareous fraction, are highly variable

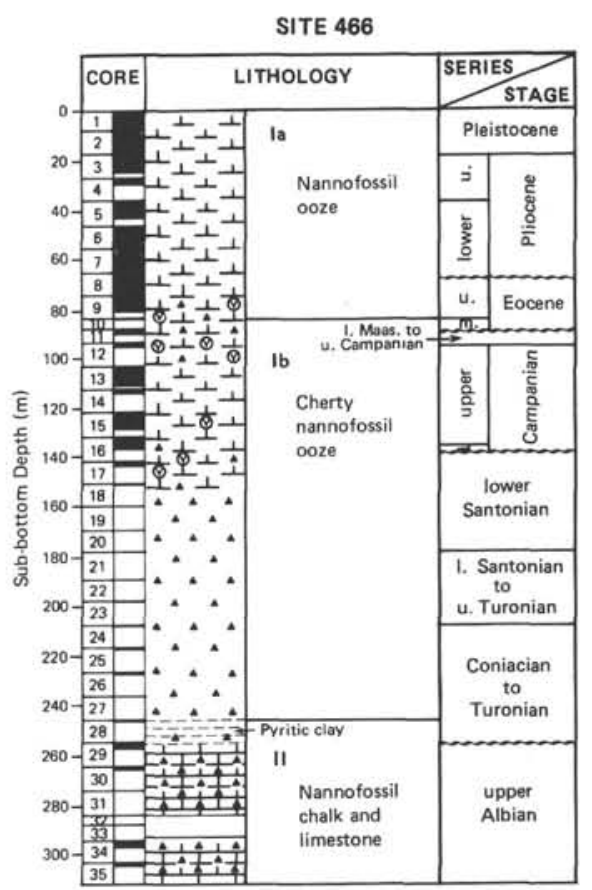

(Figs. 3 to 6; Tables 2 to 5) and fluctuate from 0 to more than $10 \mathrm{~g} \cdot \mathrm{cm}^{-2} \cdot \mathrm{yr}^{-1} 10^{-3}$. The sites reveal a common pattern of high accumulation rates in the oldest part of the penetrated sequences. The transition from high to low accumulation rates is preserved only at Sites 465 and 464 , whereas hiatuses accompany the abrupt decreases in accumulation rates at Sites 463 and 466 . The values in the younger Cenozoic parts of the sedimentary sections are low (e.g., well below $1 \mathrm{~g} \cdot \mathrm{cm}^{-2} \cdot \mathrm{yr}^{-1} 10^{-3}$ ), but the records of these time spans are incomplete at al four sites because of hiatuses (Figs. 3 to 6).

Accumulation rates for the basal phases of rapid sediment deposition are variable from site to site. They reach the highest values at Sites 463 and 465 , and fluctuate widely, revealing considerable variability of the flux of calcareous material to the sea floor. Although it is clear that the detail of stratigraphic information available is not always sufficient to establish a precise timing of these fluctuations, and although data coverage of the different time units is uneven because of the variability of the sedimentation rates, the rapidity and frequency of changes (Figs. 3 to 6) are of themselves interesting. 
J. THIEDE, D. K. REA

Table 2. Accumulation rates of bulk sediment and of the main biogenic components of Site 463 sediments.

\begin{tabular}{|c|c|c|c|c|c|c|c|}
\hline Core & $\begin{array}{l}\text { Subbottom Depth } \\
\text { (base of core, m) }\end{array}$ & $\begin{array}{l}\text { Age of } \\
\text { Base of Core } \\
\text { (m.y.) }\end{array}$ & $\begin{array}{c}\text { Bulk Mass- } \\
\text { Accumulation Rate } \\
\left(\mathrm{g} \cdot \mathrm{cm}^{-2} \cdot \mathrm{yr}^{-1} 10^{-3}\right)\end{array}$ & $\begin{array}{c}\mathrm{CaCO}_{3} \text { Chemical } \\
\text { Accumulation Rate } \\
\left(\mathrm{g} \cdot \mathrm{cm}^{-2} \cdot \mathrm{yr}^{-1} 10^{-3}\right)\end{array}$ & $\begin{array}{c}\mathrm{CaCO}_{3} \text { Fossil } \\
\text { Accumulation Rate } \\
\left(\mathrm{g} \cdot \mathrm{cm}^{-2} \cdot \mathrm{yr}^{-1} 10^{-3}\right)\end{array}$ & $\begin{array}{c}\mathrm{SiO}_{2} \text { Fossil } \\
\text { Accumulation Rate } \\
\left(\mathrm{g} \cdot \mathrm{cm}^{-2} \cdot \mathrm{yr}^{-1} 10^{-3}\right)\end{array}$ & $\begin{array}{c}\text { Organic-Carbon } \\
\text { Accumulation Rate } \\
\left(\mathrm{g} \cdot \mathrm{cm}^{-2} \cdot \mathrm{yr}^{-1} 10^{-3}\right)\end{array}$ \\
\hline $463-1$ & 5.5 & 1.8 & 0.32 & 0.27 & 0.32 & 0.0 & - \\
\hline 2 & 15.0 & 4.0 & 0.37 & 0.34 & 0.37 & 0.0 & - \\
\hline 3 & 24.5 & - & 0.28 & 0.25 & 0.28 & 0.0 & - \\
\hline 4 & 34.0 & 10.0 & 0.32 & 0.29 & 0.32 & 0.0 & - \\
\hline \multicolumn{8}{|c|}{ Hiatus $10.0-26.0 \mathrm{~m} . \mathrm{y}$, at $34.0 \mathrm{~m}$} \\
\hline 5 & 38.0 & & 0.12 & 0.11 & 0.12 & 0.0 & - \\
\hline 6 & 43.5 & 34.0 & 0.06 & 0.06 & 0.06 & 0.0 & - \\
\hline \multicolumn{8}{|c|}{$\begin{array}{l}\text { Hiatus } 34.0-44.0 \mathrm{~m} . \mathrm{y} . \text { at } 43.0 \mathrm{~m} \\
\text { Hiatus } 50-66 \mathrm{~m} . \mathrm{y} \text {. at } 46.5 \mathrm{~m}\end{array}$} \\
\hline 7 & 53.0 & 66.0 & 3.45 & 3.28 & 3.45 & 0.0 & - \\
\hline 8 & 62.5 & - & 3.04 & 2.86 & 3.04 & 0.0 & - \\
\hline 9 & 72.0 & - & 3.45 & 3.14 & 3.45 & 0.0 & - \\
\hline 10 & 81.5 & - & 3.39 & 2.88 & 3.39 & 0.0 & - \\
\hline 11 & 90.0 & - & 3.27 & 2.52 & 3.27 & 0.0 & - \\
\hline 12 & 105.5 & 68.0 & 3.72 & 3.42 & 3.72 & 0.0 & - \\
\hline 13 & 110.0 & - & 5.43 & 5.05 & 5.43 & 0.0 & - \\
\hline 14 & 119.5 & - & 4.44 & 4.13 & 4.44 & 0.0 & - \\
\hline 15 & 129.0 & - & 4.44 & 4.08 & 4.44 & 0.0 & - \\
\hline 16 & 138.5 & - & 4.47 & 4.20 & 4.47 & 0.0 & - \\
\hline 17 & 148.0 & - & 4.72 & 4.34 & 4.72 & 0.0 & - \\
\hline 18 & 157.5 & - & 4.54 & - & 4.54 & 0.0 & - \\
\hline 19 & 167.0 & - & 4.54 & 4.31 & 4.54 & 0.0 & - \\
\hline 20 & 176.5 & 70.0 & 5.68 & 5.32 & 5.68 & 0.0 & - \\
\hline 21 & 186.0 & - & 2.57 & 2.52 & 2.57 & 0.0 & - \\
\hline 22 & 195.5 & 71.0 & 2.55 & 2.35 & 2.55 & 0.0 & - \\
\hline 23 & 199.5 & - & 0.27 & 0.26 & 0.27 & 0.0 & - \\
\hline 24 & 205.0 & - & 0.30 & 0.28 & 0.30 & 0.0 & - \\
\hline 25 & 214.5 & 80.0 & 0.28 & 0.25 & 0.28 & 0.0 & - \\
\hline 26 & 224.0 & - & 3.14 & 2.89 & 3.14 & 0.0 & - \\
\hline 27 & 233.5 & - & 2.95 & 2.54 & 2.36 & 0.0 & - \\
\hline 28 & 243.0 & - & 3.19 & Chert & - & - & - \\
\hline 29 & 252.5 & - & 3.19 & 2.74 & 3.19 & 0.0 & - \\
\hline 30 & 262.0 & 82.0 & 3.90 & 3.16 & 3.90 & 0.0 & - \\
\hline 31 & 271.5 & - & 0.78 & 0.65 & 0.78 & 0.0 & - \\
\hline 32 & 281.0 & - & 0.81 & Chert & - & - & - \\
\hline 33 & 290.5 & 87.0 & 0.81 & 0.72 & 0.81 & 0.0 & - \\
\hline 34 & 300.0 & 90.0 & 0.43 & 0.39 & 0.43 & 0.0 & - \\
\hline 35 & 309.5 & - & 2.39 & 2.20 & 2.39 & 0.0 & - \\
\hline 36 & 319.0 & - & 2.66 & 0.96 & 2.66 & 0.0 & - \\
\hline 37 & 328.5 & - & 2.66 & Limestone & - & - & - \\
\hline 38 & 338.0 & 92.0 & 2.66 & 2.34 & 2.66 & 0.0 & - \\
\hline 39 & 347.5 & - & 1.30 & - & 1.30 & 0.0 & - \\
\hline 40 & 357.0 & - & 1.30 & - & 1.30 & 0.0 & - \\
\hline 41 & 366.5 & - & 1.30 & Chert & - & - & - \\
\hline 42 & 376.0 & 96.0 & 1.30 & - & 1.30 & 0.0 & - \\
\hline 43 & 385.5 & 97.0 & 1.30 & - & 1.30 & 0.0 & - \\
\hline 44 & 396.0 & - & 1.50 & - & 1.50 & 0.0 & - \\
\hline 45 & 404.5 & 99.0 & 1.50 & Chert & - & - & - \\
\hline 46 & 414.0 & - & 3.63 & Chert & - & - & - \\
\hline 47 & 423.5 & - & 3.63 & Chert & - & - & - \\
\hline 48 & 427.5 & 100.0 & 3.63 & 3.30 & 3.63 & 0.0 & - \\
\hline 49 & 433.0 & - & 3.38 & Chert & - & - & - \\
\hline 50 & 442.5 & 101.0 & 3.38 & 2.57 & 3.38 & 0.0 & 0.03 \\
\hline 51 & 452.0 & - & 1.42 & Chert & - & - & - \\
\hline 52 & 461.5 & 104.0 & 1.42 & - & 1.42 & 0.0 & - \\
\hline 53 & 471.0 & - & 3.22 & 0.90 & 3.22 & 0.0 & 0.003 \\
\hline 54 & 481.5 & - & 3.13 & - & 3.13 & 0.0 & - \\
\hline 55 & 490.0 & 106.0 & 3.02 & 2.63 & 3.02 & 0.0 & - \\
\hline 56 & 499.5 & - & 5.56 & 4.89 & 5.56 & 0.0 & 0.19 \\
\hline 57 & 509.0 & - & 5.90 & 4.72 & 5.90 & 0.0 & 0.006 \\
\hline 58 & 518.5 & - & 6.47 & 4.92 & 6.47 & 0.0 & 0.012 \\
\hline 59 & 528.0 & - & 6.24 & 4.80 & 6.24 & 0.0 & 0.01 \\
\hline 60 & 535.5 & - & 6.07 & 3.52 & 6.07 & 0.0 & 0.01 \\
\hline 61 & 537.5 & - & 6.93 & 3.81 & - & - & 0.006 \\
\hline 62 & 547.0 & 108.0 & 6.13 & 2.94 & 4.72 & 0.0 & 0.002 \\
\hline 63 & 556.5 & 112.0 & 0.51 & 0.41 & 0.44 & 0.0 & 0.0005 \\
\hline 64 & 566.0 & - & 9.98 & 6.59 & 8.98 & 0.0 & 0.001 \\
\hline 65 & 575.5 & - & 11.64 & - & 11.64 & 0.23 & - \\
\hline 66 & 585.0 & - & 9.93 & 7.84 & 6.95 & 2.98 & - \\
\hline 67 & 594.5 & - & 10.40 & 5.62 & 6.30 & 0.0 & 0.01 \\
\hline 68 & 604.0 & - & 8.79 & 4.57 & 0.09 & 0.0 & 0.001 \\
\hline 69 & 613.5 & - & 8.79 & 4.57 & 5.89 & 0.0 & 0.11 \\
\hline 70 & 623.0 & - & 9.07 & 2.39 & 7.53 & 0.0 & 0.09 \\
\hline 71 & 632.5 & - & 8.55 & 2.14 & 6.41 & 0.0 & 0.03 \\
\hline 72 & 642.0 & - & 6.46 & 3.17 & 6.20 & 0.06 & 0.03 \\
\hline 73 & 651.5 & - & 9.41 & 3.48 & 9.41 & 0.0 & 0.002 \\
\hline 74 & 661.0 & - & 7.36 & 3.97 & 6.92 & 0.07 & 0.01 \\
\hline 75 & 670.5 & - & 9.12 & 5.02 & - & - & 0.01 \\
\hline 76 & 680.0 & - & 9.12 & 4.01 & 7.30 & 0.0 & 0.01 \\
\hline 77 & 689.5 & - & 10.17 & 8.75 & - & - & 0.01 \\
\hline 78 & 699.0 & 115.0 & 10.07 & 4.33 & 6.24 & 0.0 & 0.01 \\
\hline 79 & 708.5 & - & 9.54 & 8.59 & - & - & 0.01 \\
\hline
\end{tabular}


Table 2. (Continued).

\begin{tabular}{|c|c|c|c|c|c|c|c|}
\hline Core & $\begin{array}{l}\text { Sub-bottom Depth } \\
\text { (base of core, } \mathrm{m} \text { ) }\end{array}$ & $\begin{array}{l}\text { Age of } \\
\text { Base of Core } \\
\text { (m.y.) }\end{array}$ & $\begin{array}{c}\text { Bulk Mass- } \\
\text { Accumulation Rate } \\
\left(\mathrm{g} \cdot \mathrm{cm}^{-2} \cdot \mathrm{yr}^{-1} 10^{-3}\right)\end{array}$ & $\begin{array}{c}\mathrm{CaCO}_{3} \text { Chemical } \\
\text { Accumulation Rate } \\
\left(\mathrm{g} \cdot \mathrm{cm}^{-2} \cdot \mathrm{yr}^{-1} 10^{-3}\right)\end{array}$ & $\begin{array}{c}\mathrm{CaCO}_{3} \text { Fossil } \\
\text { Accumulation Rate } \\
\left(\mathrm{g} \cdot \mathrm{cm}^{-2} \cdot \mathrm{yr}^{-1} 10^{-3}\right)\end{array}$ & $\begin{array}{c}\mathrm{SiO}_{2} \text { Fossil } \\
\text { Accumulation Rate } \\
\left(\mathrm{g} \cdot \mathrm{cm}^{-2} \cdot \mathrm{yr}^{-1} 10^{-3}\right)\end{array}$ & $\begin{array}{c}\text { Organic-Carbon } \\
\text { Accumulation Rate }\end{array}$ \\
\hline 80 & 710.5 & - & 9.46 & - & 9.46 & 0.0 & - \\
\hline 81 & 718.0 & - & 9.92 & 8.53 & 9.92 & 0.0 & 0.01 \\
\hline 82 & 727.5 & - & 8.17 & 1.39 & 7.92 & 0.0 & 0.02 \\
\hline 83 & 735.0 & - & 7.94 & 5.64 & 6.27 & 0.0 & 0.01 \\
\hline 84 & 746.5 & - & 8.59 & - & 8.59 & 0.0 & - \\
\hline 85 & 756.0 & - & 8.51 & 5.11 & 8.08 & 0.0 & 0.02 \\
\hline 86 & 765.5 & - & 9.54 & - & 9.54 & 0.0 & - \\
\hline 87 & 775.0 & 117.0 & 9.42 & - & - & - & - \\
\hline 88 & 784.5 & 119.0 & 6.15 & 4.86 & - & - & 0.01 \\
\hline 89 & 794.0 & - & 4.39 & - & 2.67 & 0.0 & - \\
\hline 90 & 803.5 & - & 4.39 & 3.59 & - & - & 0.01 \\
\hline 91 & 813.0 & - & 4.39 & $\begin{array}{l}4.39 \\
\end{array}$ & - & - & - \\
\hline 92 & 822.5 & - & 4.39 & - & - & - & - \\
\hline
\end{tabular}

Table 3. Accumulation rates of bulk sediment and of the main biogenic components of Site 464 sediments.

\begin{tabular}{|c|c|c|c|c|c|c|}
\hline Core & $\begin{array}{l}\text { Sub-bottom Depth } \\
\text { (base of core, m) }\end{array}$ & $\begin{array}{l}\text { Age of } \\
\text { Base of Core } \\
\text { (m.y.) }\end{array}$ & $\begin{array}{c}\text { Bulk Mass } \\
\text { Accumulation Rate } \\
\left(\mathrm{g} \cdot \mathrm{cm}^{-2} \cdot \mathrm{yr}^{-1} 10^{-3}\right)\end{array}$ & $\begin{array}{c}\mathrm{CaCO}_{3} \text { Chemical } \\
\text { Accumulation Rate } \\
\left(\mathrm{g} \cdot \mathrm{cm}^{-2} \cdot \mathrm{yr}^{-1} 10^{-3}\right)\end{array}$ & $\begin{array}{c}\mathrm{CaCO}_{3} \text { Fossil } \\
\text { Accumulation Rate } \\
\left(\mathrm{g} \cdot \mathrm{cm}^{-2} \cdot \mathrm{yr}^{-1} 10^{-3}\right)\end{array}$ & $\begin{array}{c}\mathrm{SiO}_{2} \text { Fossil } \\
\text { Accumulation Rate } \\
\left(\mathrm{g} \cdot \mathrm{cm}^{-2} \cdot \mathrm{yr}^{-1} 10^{-3}\right)\end{array}$ \\
\hline $464-1$ & 0.01 & & 0.13 & - & 0.0013 & 0.02 \\
\hline 2 & 13 & 2.8 & 0.13 & 0.01 & 0.01 & 0.06 \\
\hline 3 & 22.5 & 3.7 & 0.29 & 0.03 & 0.02 & 0.11 \\
\hline 4 & 32.0 & 4.4 & 0.35 & 0.0 & 0.03 & 0.11 \\
\hline 5 & 41.5 & 5.0 & 0.73 & 0.0 & 0.0 & 0.07 \\
\hline 6 & 51.0 & 15.0 & 0.05 & 0.0 & 0.0 & 0.0 \\
\hline 7 & 60.5 & 60.0 & 0.01 & 0.0 & 0.0 & 0.0 \\
\hline 8 & 70.0 & 70.0 & 0.04 & - & 0.0 & 0.0 \\
\hline 9 & 79.5 & 80.0 & 0.05 & 0.00025 & 0.0 & 0.0 \\
\hline 10 & 89.0 & 90.0 & 0.07 & 0.0011 & 0.0 & 0.0 \\
\hline 11 & 98.5 & 98.0 & 0.08 & 0.0 & 0.0 & 0.0 \\
\hline 12 & 108.0 & - & 3.42 & 0.65 & 3.16 & 0.0 \\
\hline 13 & 117.5 & - & 3.42 & 0.91 & 2.39 & 0.17 \\
\hline 14 & 127.0 & - & 3.42 & - & 2.05 & 0.0 \\
\hline 15 & 136.5 & - & 3.42 & - & 1.37 & 2.05 \\
\hline 16 & 146.0 & - & 2.97 & - & 1.93 & 0.59 \\
\hline 17 & 155.5 & - & 2.97 & - & 2.97 & 0.0 \\
\hline 18 & 165.0 & - & 2.97 & - & 2.38 & 0.45 \\
\hline 20 & 184.0 & - & 2.97 & - & 2.97 & 0.0 \\
\hline 21 & 193.5 & - & 2.97 & - & 1.71 & 0.52 \\
\hline 23 & 212.5 & - & 2.97 & - & 2.52 & 0.45 \\
\hline 24 & 222.0 & 104 & 2.97 & - & 2.67 & 0.30 \\
\hline 25 & 231.5 & - & 6.15 & - & 6.15 & 0.0 \\
\hline 26 & 241.0 & - & 6.15 & - & 5.54 & 0.62 \\
\hline 27 & 250.5 & - & 6.15 & - & 5.23 & 0.92 \\
\hline 29 & 269.5 & - & 6.15 & - & 0.98 & 0.77 \\
\hline 30 & 279 & - & 6.15 & - & 0.34 & 0.40 \\
\hline 32 & 298 & 107 & 6.58 & - & 1.32 & 0.10 \\
\hline
\end{tabular}

Data for the siliceous components are much poorer than for the calcareous material. Siliceous fossils have not often been preserved. At Site 463, they were deposited frequently only during a short interval (112 to $114 \mathrm{~m} . \mathrm{y}$. ), when they reached accumulation rates of 3 $\mathrm{g} \cdot \mathrm{cm}^{-2} \cdot \mathrm{yr}^{-1} 10^{-3}$. At Site 464 , they accumulated relatively rapidly during 100 to 107 m.y.; they are lacking in the brown-clay interval, but they occur again in modest amounts in the late Neogene (Fig. 4). Siliceous materials have been observed only sporadically in sediments of Sites 465 and 466.

Organic carbon accumulated rapidly in certain intervals during early and mid-Cretaceous times at Site 465 , on southern Hess Rise, and at Site 463, on the western Mid-Pacific Mountains. Fluxes of organic carbon, in terms of the average values calculated here, never exceeded $1 \mathrm{~g} \cdot \mathrm{cm}^{-2} \cdot \mathrm{yr}^{-1} 10^{-3}$, and organic-carbon concentrations change rapidly over short intervals of uncertain extent (Dean et al., this volume). It is therefore possible that the flux rates of organic carbon to the sediment occasionally have been much higher than is reflected by these data.

\section{CHANGES OF DEPOSITIONAL ENVIRONMENTS DURING LATE MESOZOIC AND CENOZOIC TIMES}

Mass-accumulation rates of biogenic material define the magnitude of fluxes of these components from the overlying water column for the remains of plankton, or from the water/sediment interface for the remains of 
Table 4. Accumulation rates of bulk sediment and of the main biogenic components of Site 465 sediments.

\begin{tabular}{|c|c|c|c|c|c|c|c|}
\hline Core & $\begin{array}{l}\text { Sub-bottom Depth } \\
\text { (base of core, m) }\end{array}$ & $\begin{array}{l}\text { Age of } \\
\text { Base of Core } \\
\text { (m.y.) }\end{array}$ & $\begin{array}{c}\text { Bulk Mass } \\
\text { Accumulation Rate } \\
\left(\mathrm{g} \cdot \mathrm{cm}^{-2} \cdot \mathrm{yr}^{-1} 10^{-3}\right)\end{array}$ & $\begin{array}{c}\mathrm{CaCO}_{3} \text { Chemical } \\
\text { Accumulation Rate } \\
\left(\mathrm{g} \cdot \mathrm{cm}^{-2} \cdot \mathrm{yr}^{-1} 10^{-3}\right)\end{array}$ & $\begin{array}{c}\mathrm{CaCO}_{3} \text { Fossil } \\
\text { Accumulation Rate } \\
\left(\mathrm{g} \cdot \mathrm{cm}^{-2} \cdot \mathrm{yr}^{-1} 10^{-3}\right)\end{array}$ & $\begin{array}{c}\mathrm{SiO}_{2} \text { Fossil } \\
\text { Accumulation Rate } \\
\left(\mathrm{g} \cdot \mathrm{cm}^{-2} \cdot \mathrm{yr}^{-1} 10^{-3}\right)\end{array}$ & $\begin{array}{c}\text { Organic-Carbon } \\
\text { Accumulation Rate } \\
\left(\mathrm{g} \bullet \mathrm{cm}^{-2} \cdot \mathrm{yr}^{-1} 10^{-3}\right)\end{array}$ \\
\hline $465-1$ & 1.0 & 1.5 & 0.07 & - & 0.07 & 0.0007 & - \\
\hline \multirow[t]{3}{*}{2} & $(1.0-4.0)$ & 4.0 & 0.09 & 0.07 & 0.09 & 0.0 & - \\
\hline & Hiatus & & & & & & \\
\hline & $4.0-10.5$ & 55.0 & 0.67 & 0.60 & 0.64 & 0.03 & - \\
\hline 3 & 20.0 & - & 0.69 & 0.62 & 0.67 & 0.0 & - \\
\hline 4 & 29.5 & 57.0 & 0.75 & 0.66 & 0.74 & 0.0 & - \\
\hline 5 & 39.0 & 58.0 & 0.79 & 0.70 & 0.79 & 0.0 & - \\
\hline 6 & 48.5 & 58.5 & 1.69 & 1.42 & 1.69 & 0.0 & - \\
\hline $7-9$ & Chert & - & - & - & - & - & - \\
\hline 10 & 86.5 & 68 & 0.37 & - & 0.37 & 0.0 & - \\
\hline 11 & 96.0 & 69 & $(0.93)$ & - & 0.67 & 0.01 & - \\
\hline $465 \mathrm{~A}-1$ & $39-48.5$ & 58.0 & 0.06 & 0.05 & 0.06 & 0.0006 & - \\
\hline 2 & 58.0 & 63.0 & 0.14 & Chert & - & - & - \\
\hline 3 & 67.5 & 65.0 & 0.35 & 0.31 & 0.32 & 0.004 & - \\
\hline 4 & 77.0 & - & 1.65 & Chert & - & - & - \\
\hline 5 & 86.5 & - & 1.65 & - & - & - & - \\
\hline 6 & 96.0 & - & 1.65 & Chert & - & - & - \\
\hline 7 & 105.5 & - & 1.65 & - & 1.65 & - & - \\
\hline 8 & 115.0 & - & 1.65 & 1.60 & 1.62 & 0.0 & - \\
\hline 9 & 124.5 & 68.0 & 1.65 & 1.49 & 1.65 & 0.0 & - \\
\hline 10 & 134.0 & 70.0 & 0.42 & 0.41 & 0.42 & 0.0 & - \\
\hline 11 & 143.5 & - & 8.83 & 8.57 & 8.57 & 0.0 & - \\
\hline 12 & 153.0 & - & 8.83 & 8.39 & 8.83 & 0.0 & - \\
\hline 13 & 162.5 & - & 8.17 & Chert & - & - & - \\
\hline 14 & 172.0 & - & 8.17 & Chert & - & - & - \\
\hline 15 & 181.5 & - & 8.17 & 7.84 & 8.17 & 0.0 & - \\
\hline 16 & 191.0 & - & 8.00 & 7.76 & 8.00 & 0.0 & - \\
\hline 17 & 200.5 & - & 7.57 & 7.11 & 7.57 & 0.0 & - \\
\hline 18 & 210.0 & - & 8.26 & 7.51 & 8.26 & 0.0 & 0.08 \\
\hline 19 & 219.5 & 71.0 & 7.74 & 7.43 & 7.74 & 0.0 & - \\
\hline 20 & 229.0 & 74.0 & 0.28 & 0.27 & 0.28 & 0.0 & - \\
\hline 21 & 238.5 & - & 0.31 & 0.29 & 0.30 & 0.01 & - \\
\hline 22 & 248.0 & 80.0 & 0.77 & Chert & - & - & - \\
\hline 23 & 257.5 & 82.0 & 1.16 & - & 1.04 & 0.0 & - \\
\hline 24 & 267.0 & - & 1.16 & Chert & - & - & - \\
\hline 25 & 276.5 & 86.0 & 1.16 & Chert & - & - & - \\
\hline 26 & 286.0 & 95.0 & 0.27 & 0.25 & 0.26 & 0.0 & - \\
\hline 27 & 295.5 & 100.0 & 0.47 & 0.26 & 0.42 & 0.0 & 0.01 \\
\hline 28 & 305.0 & - & 30.1 & 24.7 & 28.3 & 0.0 & 0.43 \\
\hline 29 & 314.5 & 101.0 & 29.2 & 18.3 & 28.4 & 0.0 & 0.12 \\
\hline 30 & 324.0 & - & 25.4 & 22.9 & 24.2 & 0.0 & 0.69 \\
\hline 31 & 333.5 & - & 25.4 & 22.9 & 24.2 & 0.0 & 0.13 \\
\hline 32 & 343.0 & - & 25.4 & 20.6 & 16.3 & 0.0 & 0.66 \\
\hline 33 & 352.5 & - & 22.1 & 17.9 & 17.2 & 0.0 & 0.69 \\
\hline 34 & 362.0 & - & 21.2 & 15.7 & - & - & 0.15 \\
\hline 35 & 371.5 & - & 27.9 & 19.0 & - & - & 0.88 \\
\hline 36 & 381.0 & - & 16.8 & 12.9 & - & - & 0.08 \\
\hline 37 & 390.5 & - & 22.0 & 14.1 & 20.4 & 0.0 & 0.81 \\
\hline 38 & 400.0 & - & 18.8 & 15.4 & 18.8 & 0.0 & 0.30 \\
\hline 39 & 409.5 & - & 25.1 & 20.3 & 25.1 & 0.0 & 0.73 \\
\hline 40 & 419.0 & - & 25.0 & 20.2 & 9.2 & 0.0 & 0.05 \\
\hline
\end{tabular}

benthos, into the sedimentary column. These fluxes reflect more than the original production of either siliceous or calcareous components, or even of organic carbon, because reworking, dissolution, and diagenetic changes have altered their original values. We still presume that the major preserved trends allow us to make inferences about the late Mesozoic and Cenozoic paleoenvironments of the central North Pacific Ocean. From late Mesozoic and Cenozoic plate movements and from the subsidence of the Mid-Pacific Mountains and of Hess Rise, we have reconstructed the paleogeographic and paleobathymetric evolution of these two structural highs (Figs. 7 and 8). The plate rotations have been carried out following the model of Lancelot (1978), because magnetic properties of the Leg 62 rocks from the Mid-Pacific Mountains and from Hess Rise (Sayre, this volume) are in better agreement with this model than with previously published, slightly different ones (Winterer, 1973; van Andel et al., 1975).

\section{Mid-Pacific Mountains}

The subsidence of Site 463 on the western MidPacific Mountains cannot properly be established at the present time, because volcanic basement was not reached. The increasing frequency and thickness of horizons of displaced calcareous shallow-water components with increasing age in the oldest part of the section document the close proximity of regions near or above the sea surface (see also Ferry and Schaaf, this volume). The addition of material displaced from the shallow areas ceased during the Aptian, approximately 112 m.y. ago, at Site 463. Indicators of shallow depositional environments during Aptian to Cenomanian time have been dredged from the tops and flanks of a number of guyots of the Mid-Pacific Mountains (Hamilton, 1956). Subaerially extruded, heavily weathered basalts overlain by shallow-water carbonates were reached at DSDP Site 171 (Winterer, Ewing, et al., 1973). These 
Table 5. Accumulation rates of bulk sediment and of the main biogenic components of Site 466 sediments.

\begin{tabular}{|c|c|c|c|c|c|c|c|}
\hline Core & $\begin{array}{l}\text { Sub-bottom Depth } \\
\text { (base of core, m) }\end{array}$ & $\begin{array}{c}\text { Age of } \\
\text { Base of Core } \\
\text { (m.y.) }\end{array}$ & $\begin{array}{c}\text { Bulk Mass } \\
\text { Accumulation Rate } \\
\left(\mathrm{g} \cdot \mathrm{cm}^{-2} \cdot \mathrm{yr}^{-1} 10^{-3}\right)\end{array}$ & $\begin{array}{c}\mathrm{CaCO}_{3} \text { Chemical } \\
\text { Accumulation Rate } \\
\left(\mathrm{g} \cdot \mathrm{cm}^{-2} \cdot \mathrm{yr}^{-1} 10^{-3}\right)\end{array}$ & $\begin{array}{c}\mathrm{CaCO}_{3} \text { Fossil } \\
\text { Accumulation Rate } \\
\left(\mathrm{g} \cdot \mathrm{cm}^{-2} \cdot \mathrm{yr}^{-1} 10^{-3}\right)\end{array}$ & $\begin{array}{c}\mathrm{SiO}_{2} \text { Fossil } \\
\text { Accumulation Rate } \\
\left(\mathrm{g} \cdot \mathrm{cm}^{-2} \cdot \mathrm{yr}^{-1} 10^{-3}\right)\end{array}$ & $\begin{array}{c}\text { Organic-Carbon } \\
\text { Accumulation Rate } \\
\left(\mathrm{g} \cdot \mathrm{cm}^{-2} \cdot \mathrm{yr}^{-1} 10^{-3}\right)\end{array}$ \\
\hline $466-1$ & 8.0 & 1.0 & 0.55 & 0.45 & 0.51 & 0.04 & - \\
\hline 2 & 17.5 & 1.8 & 0.84 & 0.68 & 0.76 & 0.02 & - \\
\hline 3 & 27.0 & - & 1.12 & 0.95 & 1.09 & 0.04 & - \\
\hline 4 & 36.5 & 3.0 & 1.20 & 1.08 & 1.18 & 0.04 & - \\
\hline 5 & 46.0 & - & 2.33 & 2.12 & 2.26 & - & - \\
\hline 6 & 55.5 & - & 2.36 & 1.95 & 2.34 & 0.02 & - \\
\hline 7 & 65.0 & - & 2.30 & 2.07 & 2.25 & 0.02 & - \\
\hline \multirow{2}{*}{\multicolumn{3}{|c|}{$\begin{array}{c}74.5 \\
\text { Hiatus } 4-38.0 \text { m.y. at } 6 \overline{\mathrm{m}}\end{array}$}} & 2.77 & 2.41 & 2.71 & 0.0 & - \\
\hline & & & - & - & - & - & \\
\hline 9 & 84.0 & - & 0.13 & 0.12 & 0.12 & 0.0 & 0.01 \\
\hline \multirow{2}{*}{\multicolumn{8}{|c|}{$\begin{array}{l}88.0 \\
\text { Hiatus } 48-70 \text { m.y. }\end{array}$}} \\
\hline & & & & & & & \\
\hline 12 & 103.0 & - & $\begin{array}{l}4.37 \\
3.38\end{array}$ & $\begin{array}{l}4.28 \\
3.28\end{array}$ & - & -0.04 & $\bar{z}$ \\
\hline 13 & 112.6 & - & 3.38 & 3.28 & 3.31 & 0.0 & - \\
\hline 14 & 122.0 & - & 3.31 & 3.11 & - & - & - \\
\hline 15 & 131.5 & 71 & 3.31 & 3.18 & 3.08 & 0.0 & - \\
\hline 16 & 141.0 & - & 0.52 & 0.49 & 0.52 & 0.0 & - \\
\hline 17 & 150.5 & - & 0.52 & 0.50 & 0.52 & 0.0 & - \\
\hline 18 & 160.0 & - & 0.52 & Chert & - & - & - \\
\hline 19 & 169.5 & - & 0.52 & Chert & - & - & - \\
\hline 20 & 179.0 & - & 0.52 & Chert & - & - & - \\
\hline 21 & 188.5 & 81 & 0.52 & Chert & - & - & - \\
\hline 22 & 198.0 & - & 1.93 & Chert & - & - & - \\
\hline 23 & 207.5 & - & 1.93 & Chert & - & - & - \\
\hline 24 & 217.0 & 84 & 1.93 & Chert & - & - & - \\
\hline 25 & 226.5 & - & 3.86 & Chert & - & - & - \\
\hline 26 & 236.0 & - & 3.86 & Chert & - & - & - \\
\hline 27 & 245.5 & - & 3.86 & Chert & - & - & - \\
\hline 28 & 255.0 & 86 & 3.86 & Chert & - & - & - \\
\hline 29 & 264.5 & 100 & 0.14 & 0.10 & 0.11 & 0.0 & 0.01 \\
\hline 30 & 274.0 & - & 11.83 & 10.29 & 10.88 & 0.0 & - \\
\hline 31 & 283.5 & - & 8.46 & - & 7.44 & 0.08 & - \\
\hline 32 & $\begin{array}{c}287.5 \\
\text { (no recovery) }\end{array}$ & - & 8.46 & - & - & - & - \\
\hline 33 & $\begin{array}{c}293.0 \\
\text { (no recovery) }\end{array}$ & - & 8.46 & - & - & - & - \\
\hline 34 & 302.5 & - & 8.46 & 7.19 & - & - & 0.08 \\
\hline 35 & 312 & 101 & 8.46 & 6.35 & 7.78 & 0.0 & 0.22 \\
\hline
\end{tabular}

lithologies document for the Mid-Pacific Mountains a subsidence well in excess of $2 \mathrm{~km}$ during the past 100 m.y. Following the model of Lancelot (1978), Site 463 was situated roughly at $20^{\circ} \mathrm{S}, 150^{\circ} \mathrm{W} 120 \mathrm{~m}$.y. ago; by $90 \mathrm{~m} . \mathrm{y}$. ago, it had moved to $12^{\circ} \mathrm{S}, 160^{\circ} \mathrm{W}$; it crossed the equator 60 to $70 \mathrm{~m}$.y. ago, then continued its northwesterly movement into the central North Pacific. If we assume that the volcanic events which led to the construction of the dominant portion of the Mid-Pacific Mountains had ceased at the time of deposition of the oldest sediments at Site 463 (approximately 120 m.y. ago), then this structural high must have been a group of large and small islands whose extent diminished with increasing subsidence. The large islands would have exerted an important influence upon the hydrography of the surface-water masses and upon the depositional environments in the submarine regions adjacent to them. It probably explains the long duration of the phase of high accumulation rates at Site 463 beginning 120 m.y. ago, and the high variability of fluxes of biogenic components (Fig. 3).

\section{Hess Rise}

The paleogeographic and paleobathymetric evolution of Hess Rise (Fig. 8) reveals trends similar to those found in the Mid-Pacific Mountains, although this structural high is situated approximately 15 degrees of latitude farther north. Its northern part (Fig. 8) had crossed the equatorial region prior to $100 \mathrm{~m}$.y. ago. The concomitant large increase in accumulation rates just above the volcanic basement at Site 464 (Fig. 4) probably reflects the location of this site under the equatorial current regime, where productivity is high (van Andel et al., 1975) and where the CCD is depressed more than usual in response to the high flux of calcareous particles to the sea floor (Berger and Winterer, 1974). The southern part of Hess Rise must have risen above the sea surface to form groups of tropical islands. Most of these islands sank below sea level during Late Cretaceous time when Hess Rise crossed the equatorial zone. Only Mellish Seamount, if it existed at all, may have existed as an island until sometime in the late Tertiary, and occasionally in Quaternary time. The presence of, first, a chain of large islands and, later, of extensive shallow bank areas must have disturbed the equatorial current regime as Hess Rise moved northward, and this may have caused the development of a wide area of high surface-water productivity, which would have existed until the rise moved out of the region with continuing northward plate movement (Lancelot, 1978). During this time, limestones and chalks with high concentrations of organic carbon (Dean et al., this volume) were deposited along the flanks of southern Hess Rise at relatively shallow water depths, as documented by the occurrence of benthic foraminifers (see site reports, this volume). However, the significant fluctuations of accumulation 


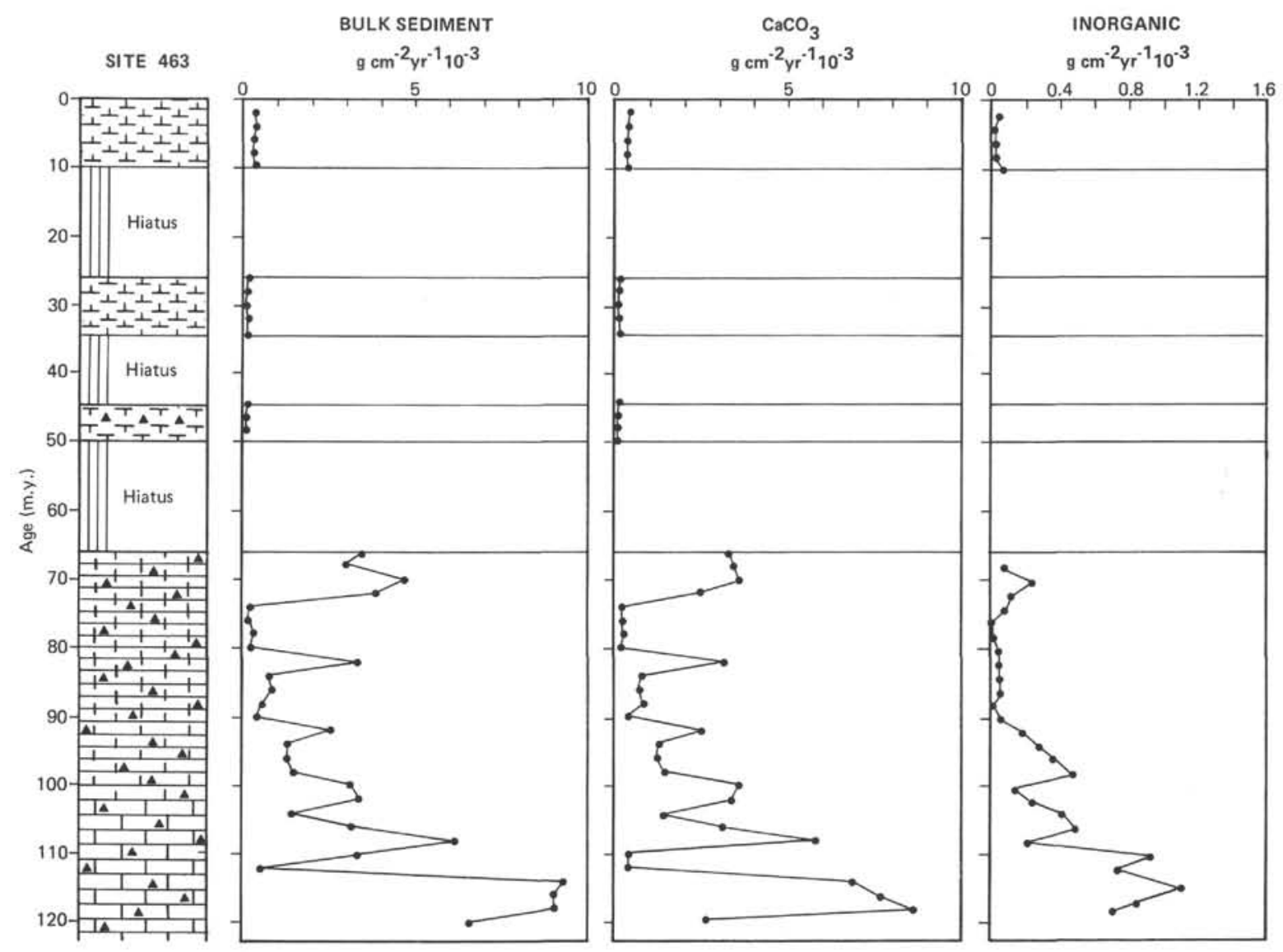

Figure 3. Distribution of accumulation rates of the bulk sediment, of $\mathrm{CaCO}_{3}$ fossil, and of eolian material at Site 463 (MidPacific Mountains). The accumulation rate of the inorganic, crystalline, non-authigenic, eolian material has been taken from Rea and Janecek (this volume).

rates, the sedimentary structures in the organic-rich limestones, and the reworked shallow-water material which occurs at the unconformity on top of the Mesozoic section all document how variable and unstable this depositional environment has been.

During Cenozoic times, all four sites on Hess Rise had reached a position under the sterile subtropical gyre, where accumulation rates were low and where erosional processes of wide extent generated long hiatuses. A thick brown-clay sequence of Cretaceous to Miocene age (Doyle and Riedel, this volume; Sancetta, this volume) documents the position of Site 464, well below the CCD for long periods of time. Dissolution of calcareous material was also important at the other sites at intermediate depths (1.5-2.5 km), which had been expected to be much less prone to calcite dissolution than they proved to be.

In comparing the accumulation rates of the bulk sediments and of the biogenic components, it is apparent that both variables reflect the same signal, because these sediments (except the brown clays at Site 464) are composed almost entirely of biogenic calcareous particles of planktonic origin. It is therefore interesting that the trends displayed by the accumulation rates of the crystalline, non-authigenic, inorganic material of probably eolian or volcanic origin (Rea and Janecek; Rea and Harrsch; both this volume) mimicked in part those of the biogenic components, although individual values are much smaller (Fig. 3).

\section{The Pelagic Depositonal Paleoenvironments Close to Submarine Elevations}

Anomalously shallow regions of the deep old Pacific basins are found near volcanic aseismic rises which reach close to the sea surface, or through the sea surface if they bear islands. They represent an obstacle to the current regimes of the oceanic surface water masses, generating a region of enhanced surface-water productivity because of bathymetrically-induced upwelling of nutrient-enriched waters to the sea surface, and because of the additional nutrient influx from large-island runoff. If the rises reach into the photic zone or higher, they can support highly productive neritic depositional environments with locally rapid bottom currents, and they may receive important contributions of erosional products from the subaerial volcanic edifices of adjacent large and small islands. A modern analogy of such a pelagic environment probably occurs in the depositional regime around the Galapagos Islands (Moore et al., 1973), in the eastern tropical Pacific Ocean.

The sedimentary columns drilled during DSDP Leg 62 on the Mid-Pacific Mountains and on Hess Rise document the depositional history of two large midPacific aseismic rises which were built during a phase of 


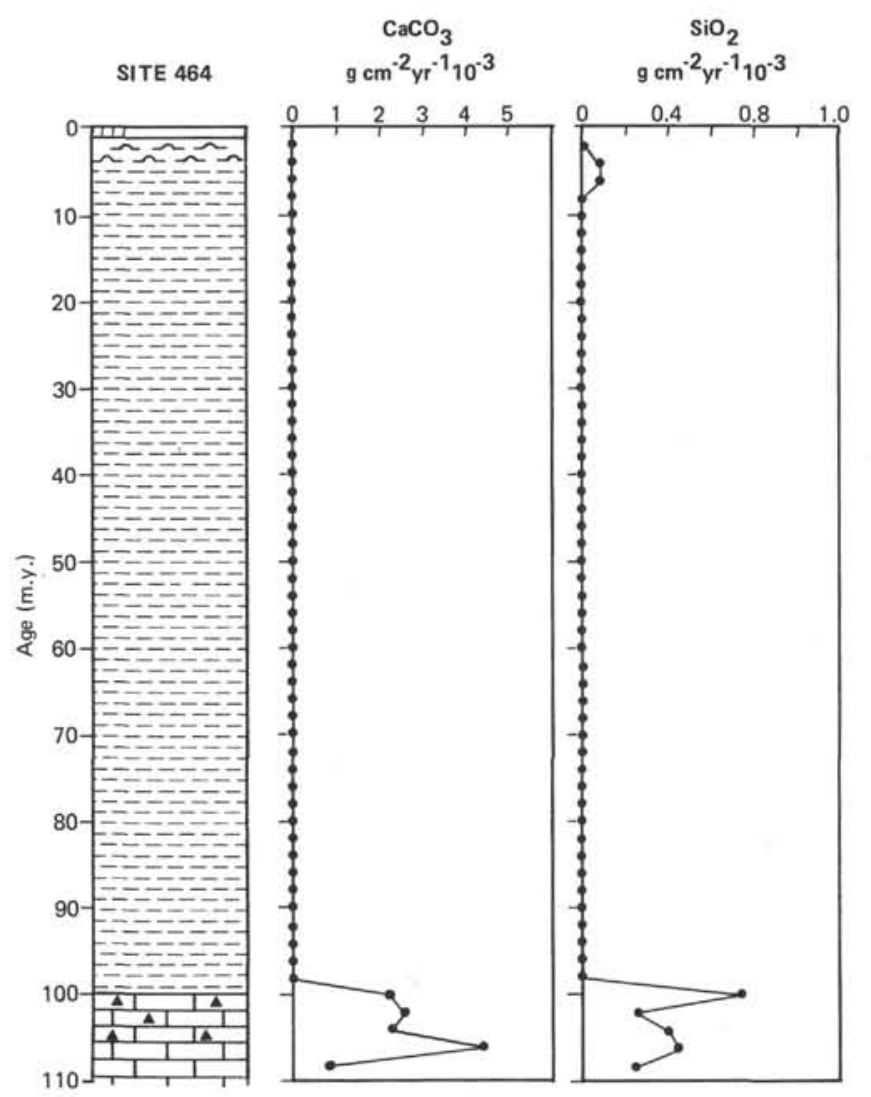

Figure 4. Distribution of $\mathrm{CaCO}_{3}$ fossil and $\mathrm{SiO}_{2}$ fossil accumulation rates at Site 464 (northern Hess Rise). intensive early Cretaceous volcanic activity south of the Equator and which once represented large tropical islands (Figs. 7 and 8). These islands subsided rapidly after their formation, but parts of the rises remained as shoal areas as this part of the Pacific plate moved northward across the Equator into the central subtropical and temperate North Pacific Ocean. The accumulation rates of inorganic sediment components (Rea and Janecek, this volume) were high during the early phase (Fig. 3) of the depositional history of the Mid-Pacific Mountains, when erosional products from the oceanic islands and carbonate debris from the neritic regions surrounding them were shed over the island slope, especially during phases of low sea levels (Vail et al., 1977; Thiede et al., this volume).

The accumulation rates of the bulk sediments were high during the Early and middle Cretaceous histories of both the Mid-Pacific Mountains (Site 463) and the southern part of Hess Rise (Sites 465 and 466), because these regions were situated far above the CCD and because they received an additional input of displaced shallow-water material. Hess Rise crossed the equatorial region of the Cretaceous Pacific Ocean 30 m.y. earlier (Site 464) than the Mid-Pacific Mountains. The traverse of the shallow regions across the westward-flowing equatorial current regime generated a time-transgressive pelagic depositional environment characterized by highly variable accumulation rates (Sites 465 and 463), the development of important hiatuses (Sites 465 and 466), and sediments with high concentrations of opaline fossils, which is typical of very productive surface-water

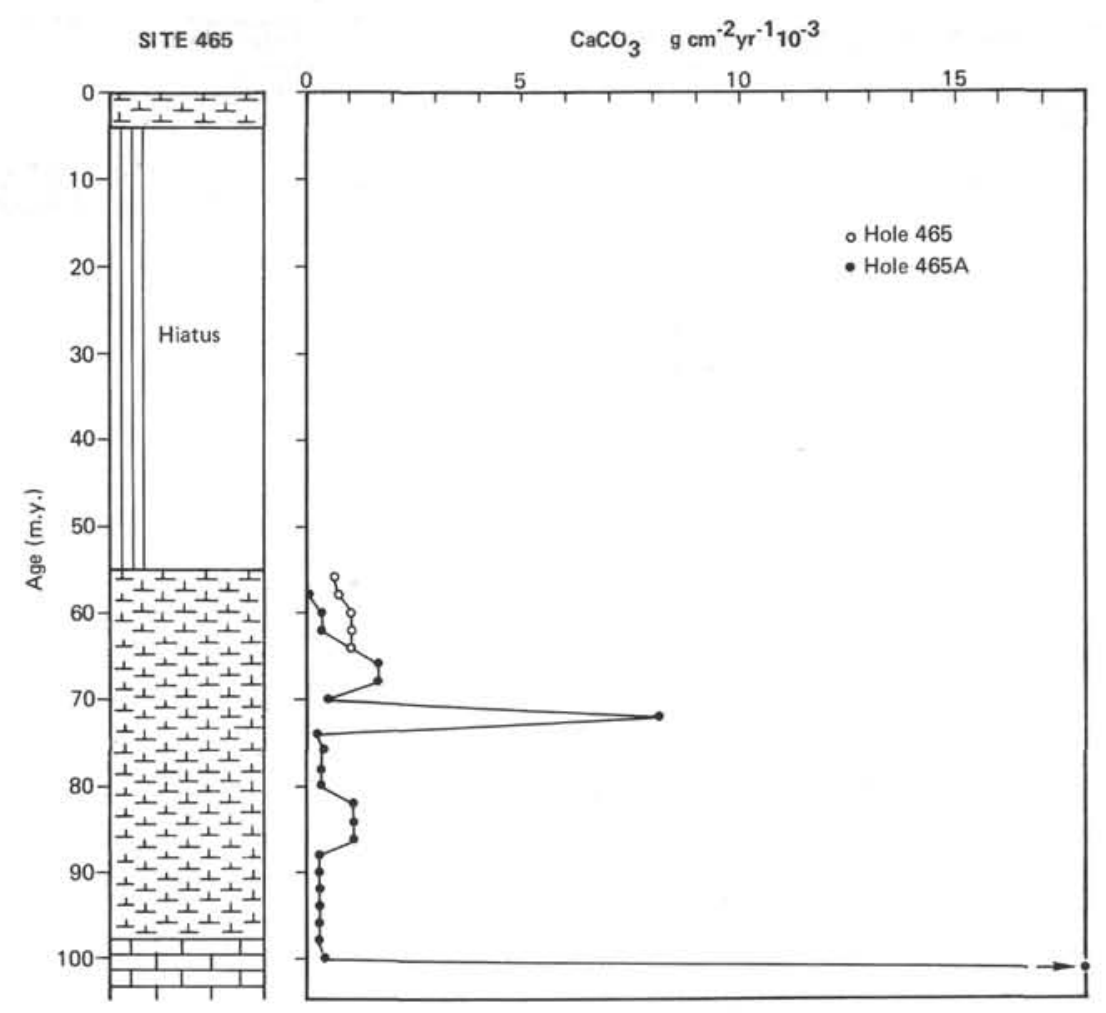

Figure 5. Distribution of $\mathrm{CaCO}_{3}$ fossil accumulation rates at Site 465 (southern Hess Rise). 


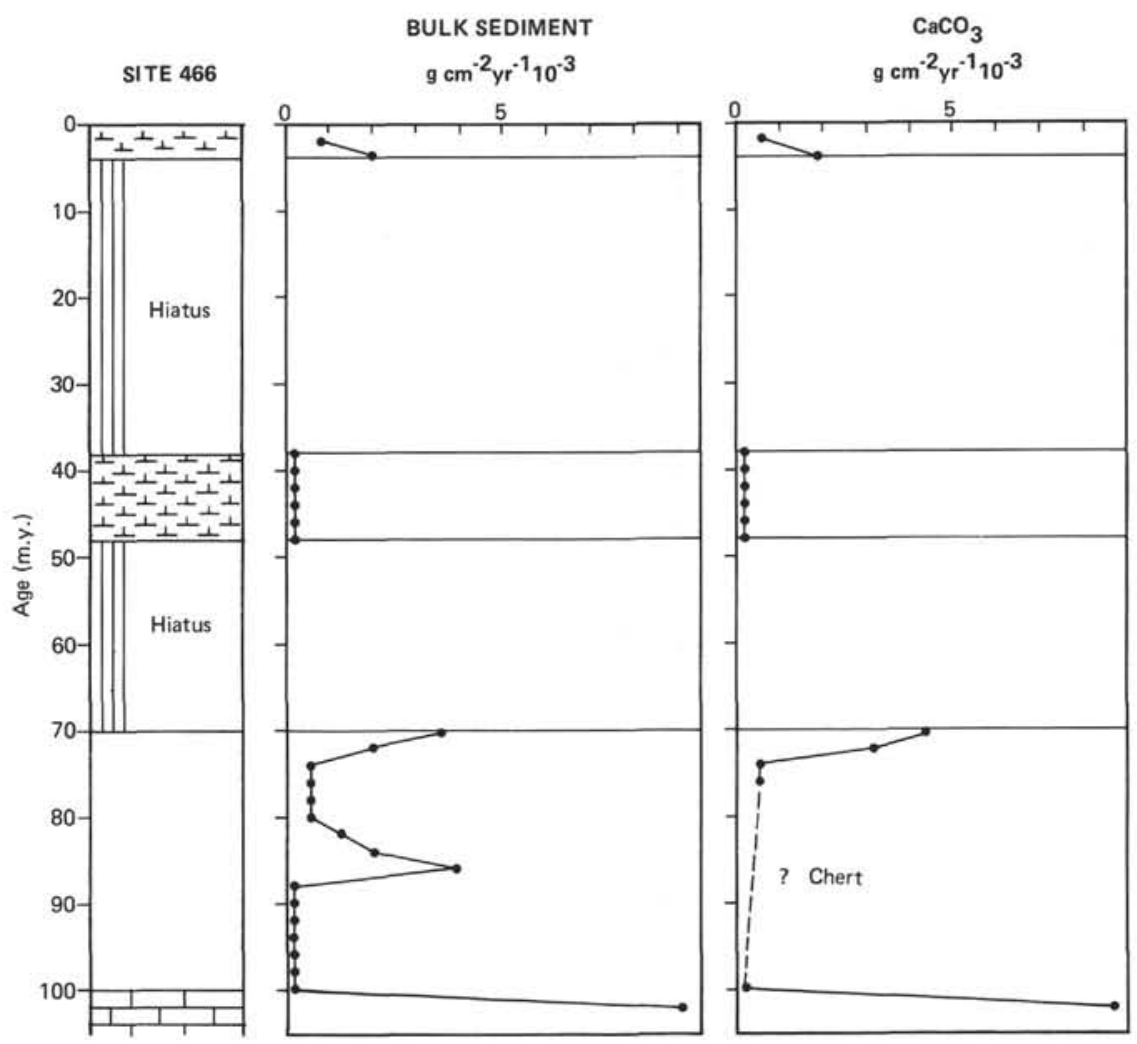

Figure 6. Distribution of accumulation rates of the bulk sediment and of $\mathrm{CaCO}_{3}$ fossil at Site 466 (southern Hess Rise).

masses, and which in part resulted in the frequent occurrence of chert in the Upper Cretaceous sequences. Accumulation rates of the pelagic sediments laid down while crossing under the equatorial divergence are higher than before and after, because the high flux of calcareous components depressed the CCD more (Berger and Winterer, 1974) than north or south of the Equator. This depositional environment is expressed in the sedimentary record of all Leg 62 sites by higherthan-usual accumulation rates of calcareous pelagic deposits, but the effect of the equatorial crossing is best seen at Site 464, on the northern Hess Rise (Fig. 4). This site is the deepest and the northernmost location drilled during Leg 62. The zone of high carbonate accumulation rates is 100 to $110 \mathrm{~m} . \mathrm{y}$. old, and it is accompanied by high accumulation rates of siliceous fossils; during the past 100 m.y., the depositional environment of this site has been characterized by a very slow accumulation of brown pelagic and siliceous clays. Laminated, organic-carbon-rich, thick limestone and chalk deposits penetrated at the bottom of Sites 465 and 466 document the traverse of southern Hess Rise under the equatorial divergence 99 to 102 m.y. ago. This region was characterized by shallow-water depths (probably less than 1000 $\mathrm{m})$, where pelagic sediments accumulated, by a strong mid-water oxygen minimum resulting from high surface-water productivity, and by bottom-water current speeds sufficient to erode and winnow the soft, finegrained pelagic sediments (Dean et al., this volume).

The Leg 62 sites on the Mid-Pacific Mountains and on Hess Rise had reached the sterile subtropical to tem- perate central North Pacific by the time they had subsided into intermediate and deep waters. The calcareous pelagic components of the Cenozoic sediments are therefore either dissolved (Site 464), or only partially preserved or fragmented (Vincent, this volume), and the continuity of the Cenozoic sedimentary sequences has been interrupted by erosion. Accumulation rates of the Cenozoic sediments of all sites-whether they encompass siliceous, calcareous, or clayey sediments-are therefore very low in comparison to the Mesozoic accumulation rates.

\section{ACKNOWLEDGMENTS}

This paper is based on data collected through the joint effort of the shipboard party of Deep Sea Drilling Project Leg 62. The manuscript benefitted from the critical comments of T. Vallier (Menlo Park) and C. G. Adelseck (La Jolla), which are gratefully acknowledged.

\section{REFERENCES}

Berger, W. H., and Winterer, E. L., 1974. Plate stratigraphy and the fluctuating carbonate line. Internat. Assoc. Sedimentol. Spec. Pub., 1:11-48.

Berggren, W. A., and Van Couvering, J. A., 1974. The late Neogene. Palaeogeogr., Palaeoclimatol., Palaeoecol., 16:1-216.

Bode, G. W., 1973. Carbon and carbonate analyses. In Kulm, L. D., von Huene, R., et al., Init. Repts. DSDP, 18: Washington (U.S. Govt. Printing Office), 1069-1076.

Boyce, R. E., and Bode, G. W., 1972. Carbon and carbonate analyses, Leg 9. In Hays, J. D., et al., Init. Repts. DSDP, 9: Washington (U.S. Govt. Printing Office), 797-816.

Chase, T. E., Menard H. W., and Mammerickx, J., 1971. Topography of the North Pacific: La Jolla (Inst. Mar. Res., Univ. Cal. San Diego).

Hamilton, E. L., 1956. Sunken islands of the Mid-Pacific Mountains. Geol. Soc. Am. Mem., 64. 
Hardenbol, J., and Berggren, W. A., 1978. A new Paleogene numerical time scale. Amer. Assoc. Petrol. Geol. Stud. Geol., 6:213234.

Lancelot, Y., 1978. Relations entre évolution sédimentaire et tectonique de la plaque Pacifique depuis le Cretacée inferieur. Soc. Géol. France Mém. N.S., 134.

Lancelot, Y., and Larson, R. L., 1975. Sedimentary and tectonic evolution of northwestern Pacific. In Larson, R. L., Moberly, R., et al., Init. Repts. DSDP, 32: Washington (U.S. Govt. Printing Office), 233-293.

Moore, T. C., Heath, G. R., and Kowsmann, R. O., 1973. Biogenic sediments of the Panama Basin. J. Geol., 81:458-472.

Müller, G., and Gastner, M., 1971. The 'Karbonat-Bombe,' a simple device for determination of the carbonate contents in sediments, soils and other materials. N. Jahrb. Mineral. Monatsh., 10: 466-469.

Rea, D. K., and Thiede, J., 1981, Mesozoic and Cenozoic mass accumulation rates of the major sediment components in the Nauru
Basin, western equatorial Pacific. In Larson, R. L., Schlanger, S., et al., Init. Repts. DSDP, 61: Washington (U.S. Govt. Printing Office), 549-556.

Shipboard Scientific Party, 1973. Site 171. In Winterer, E. L., Ewing, J. I., et al., Init Repts. DSDP, 17: Washington (U.S. Govt. Printing Office), 283-334.

Vail, P. R., Mitchum, R. M., and Thompson, S., 1977. Seismic stratigraphy and global changes of sea level. Part 3: relative changes of sea level from coastal onlaps. Part 4: global cycles of relative changes of sea level. Am. Assoc. Petrol. Geol. Mem., 36:63-97.

van Andel, T. H., Heath, G. R., and Moore, T. C., 1975. Cenozoic history and paleoceanography of the central equatorial Pacific Ocean. Geol. Soc. Am. Mem., 143.

van Hinte, J. E., 1976. A Cretaceous time scale. Am. Assoc. Petrol. Geol. Bull., 60:498-516.

Winterer, E. L., 1973. Sedimentary facies and plate tectonics of the equatorial Pacific. Am. Assoc. Petrol. Geol. Bull., 57:265-282. 

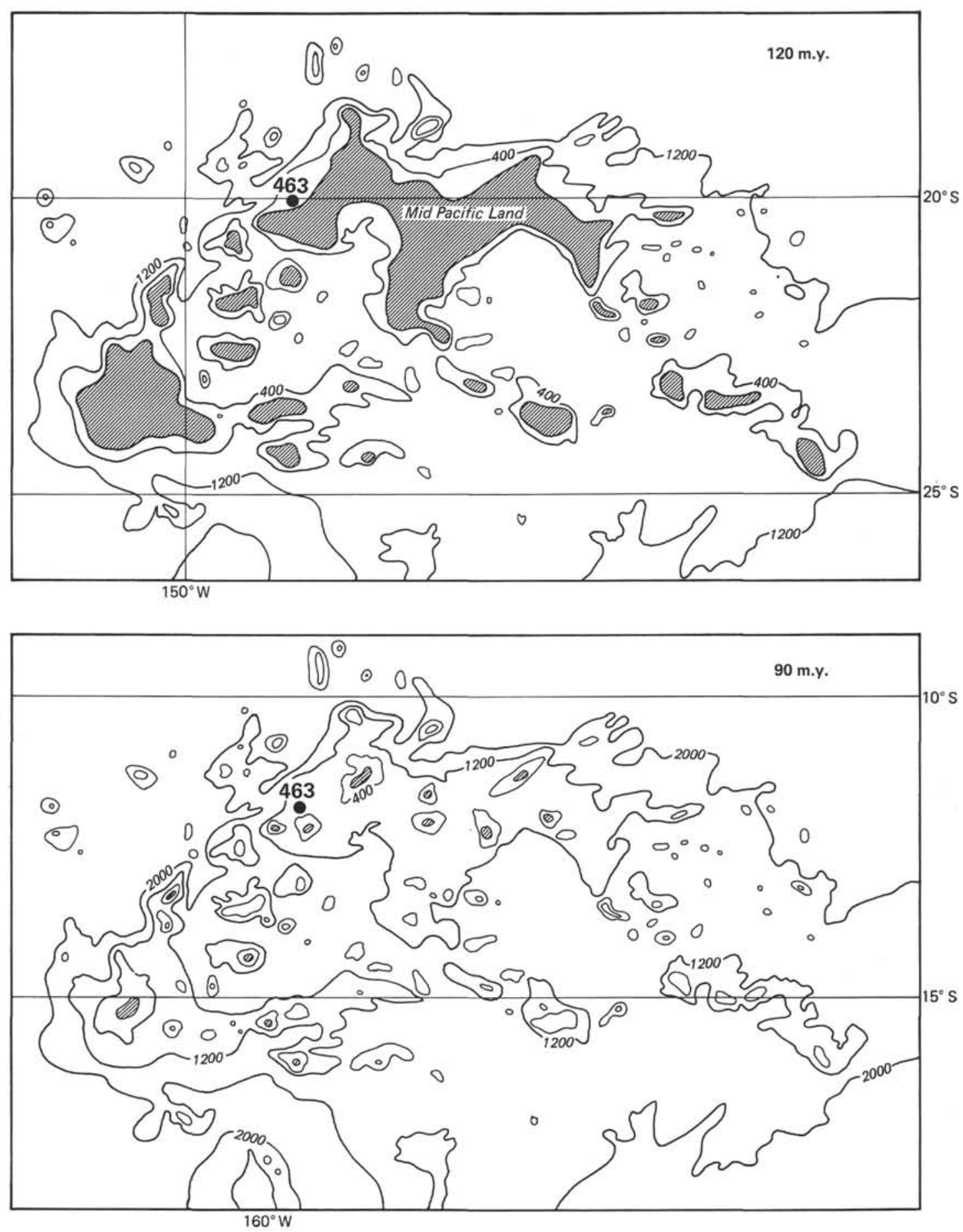

Depths in Fathoms

Figure 7. Paleobathymetry and paleogeography of the Mid-Pacific Mountains approximately 120 and 90 m.y. ago, in comparison with the modern morphology. The paleolatitude has been reconstructed from plate rotations, according to the model of Lancelot (1978). For the modern bathymetry, see Figure 1. 

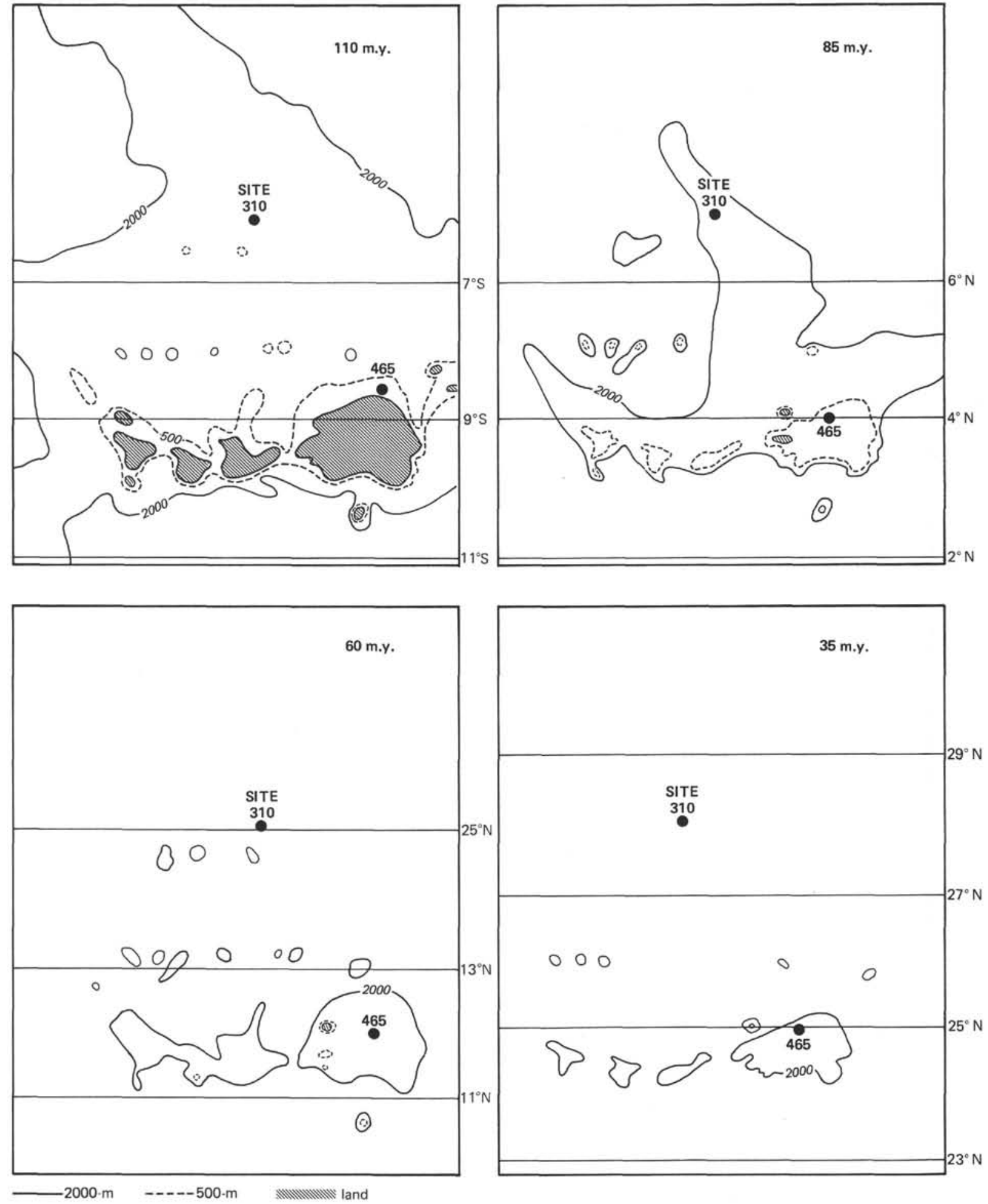

Figure 8. Paleogeographic and paleobathymetric conditions of Hess Rise during the past 110 m.y. The paleolatitude of Hess Rise has been reconstructed from plate rotations, after the model of Lancelot (1978). For the modern bathymetry, see Figure 1. 